\title{
GRM1 wt Allele
}

National Cancer Institute

\section{Source}

National Cancer Institute. GRM1 wt Allele. NCI Thesaurus. Code C51462.

Human GRM1 wild-type allele is located within $6 q 24$ and is approximately $410 \mathrm{~kb}$ in length. This allele, which encodes metabotropic glutamate receptor 1 protein, plays a role in the regulation of glutamatergic neurotransmission and phospholipase $\mathrm{C}$ activation. 